\title{
Quo Vadis of Bureaucracy Reformation on Health Sector in Perspective of Neo Weberian State
}

\author{
Muhammad Amir $^{1}$, Syahri Nehru Husain ${ }^{2}$, Eka Suaib ${ }^{3}$, Syamsul Alam ${ }^{4}$ \\ 1, 2, 3, 4 Halu Oleo University Faculty of Administration, Department of Public Administration, Kendari, Indonesia
}

\begin{abstract}
Trajectory is departed from an initial point (alpha) on a future desired state (omega). Their elements are overall forming the bureaucratic reform scenario.This study used Perspective of Neo Weberian State (NWS), which included the five principles of bureaucratic reform, such as the bureaucracy external orientation to the fulfillment of citizens' needs; the strategic role of professional managers in the implementation of policies; collaboration of public and private sector; representative democracy which is supported by public consultation and participation; and the separation of politics-administration with an emphasis on administration professionalism. The results showed that the reform of government bureaucracy in Kendari run in a zig-zag that not follow to the intentional pattern or trajectory which focus clearly. Traditional patrimonial cultures were a cause of bureaucratic reform that not go in accordance with NWS trajectory models. As a result, bureaucratic reform did not lead to significant changes for professional employees' and was still characterized by the coexistences between modern and patrimonial.
\end{abstract}

Keywords: Bureaucracy Reformation, Neo Weberian State, Trajectory, Organizational Culture

\section{Introduction}

Bureaucracy reform is very important for developing countries, including Indonesia because in bureaucracy states was the main engine of government sector, otherwise the bureaucracies has a lack of capacity to facilitate the tasks of government effectively, thus, bureaucratic reforms are very functional for development success (Farazmand 2002 ).

Because of international organizations influenced, bureaucratic reform in developing countries generally follows a general model of New Public Management (NPM). NPM Model was a phenomenon in developing countries, especially for Anglo-Saxon (Hughes, 2003). NPM Model focuses on managerial discretion, personal skills to perform specific managerial roles effectively, and institutionalization of values that go beyond the formal structures control, such as responsibility and democracy (Lynn, 2006).

Recently, the bureaucratic reform in Indonesia has covered various sectors included health sector which is important for Indonesia that still in crisis of health system till now. Health system performance was generally poor and only slightly improvement during the period of 2001 to 2007. Even though, during this period, Indonesian government has spent a significant amount of budget for health care financing (Heywood \& Choi, 2010).

Indonesian's government has been engaged intensively in bureaucratic reform efforts on health sector which particularly has issued the act of Ministry State No. 25 in 2008 on General Guidelines for Bureaucracy Reforms. Then, the government was following up with the reformation through the Regulation of President No. 81/2010 on Grand Design of Bureaucracy Reforms. Bureaucratic reform is going on to efforts to modernize the traditional employees' state, in order to become more professional. Moreover, professional employees are more efficient and responsive to citizens (Pollitt \& Bouckaert, 2004, 2011).
Bureaucratic reforms literature suggests a model of NeoWeberian State (NWS) coined by Pollitt \& Bouckaert to be a reference for developing countries. NWS is considered as an appropriate model because Weberian classical bureaucracy deemed to have virtues that must be maintained, such as clarity of accountability and attention to the law. Public sector reform in developing countries firstly needs to resolve these issues before reaching the managerial problems (Hintea 2011; Cepiku \& Mititelu, 2010). The key is to find out a better combination with an efficient procedures and responsive to the citizens' needs (Pollitt \& Bouckaert, 2011).

Government in Kendari City has conducted a bureaucratic reform effort referred to a national agenda, but this reformation has still limited by the budget for public programs so that the local governments have not be able to create enough jobs, reduce poverty and achieve social outcomes targeted. Moreover, the attainments of poor social outcomes are existed in health sector in Kendari. The problems that stand in the healthcare sector were the death rate, prevalence of malnutrition and morbidity. Infant mortality rate (in 2010) was $34 \%$ per 10,000 live births, child mortality rate (in 2010) was $7 \%$ per 10,000 live births, the maternal mortality rate (in 2007) was $5.7 \%$ per 10,000 live births, the prevalence of underweight children (in 2010) was $5.1 \%$, and malaria disease (in 2011) was amounted to $14.54 \%$ (BPS, 2013).

Neo Weberian State (NWS) Model was proposed by Pollitt \& Bouckaert in 2004 in order to explain the differences of governance among three groups of governance in the country, namely the maintainers, the modernizers and the marketizers. Two of these three groups had primary concern to the reform, namely the Anglo-American NPM marketizers and Continental European modernizers. Reform model of Continental European Modernizers is classified by Pollitt \& Bouckaert as NWS.

Pollitt \& Bouckaert (2004) are proposed to the NWS as a conceptual map, a summary description and not as a normative model or a theory. This model is intended to 


\section{International Journal of Science and Research (IJSR) \\ ISSN (Online): 2319-7064 \\ Index Copernicus Value (2013): 6.14 | Impact Factor (2014): 5.611}

understand what taking place in Europe is. NWS describes an omega, which is a destination, an ideal world to be achieved, a vision of a desired future (Pollitt \& Bouckaert, 2004, 2011). This omega situation might be a critique to the initial situation, status quo, or an alpha. NWS as an omega has a function as a vision of modern state employees, efficient, and friendly to citizens.

Omega situation required a trajectory, which is an intentional pattern, attempted a route taken. Trajectory is departed from an initial point (alpha) towards a desired state in the future (omega). An omega without a trajectory and an alpha is just a utopia (Pollitt \& Bouckaert, 2004, 2011). The elements of initial conditions (alpha), trajectory, and the future state (omega) was overall form the reform scenarios.

NWS as a conceptual map or summary description does not provide an analytical framework to analyze the reform experience in governments. However, based on the conceptual maps it can be developed a typology to classify, or specific theories to explain specific patterns and bureaucratic reforms trends (Pollitt \& Bouckaert, 2004, 2011). For example, Cepiku \& Mititelu (2010) were developed an NWS analytical framework of Pollitt \& Bouckaert in order to analyze the public administration reform experiences in different cultural contexts, especially in developing countries.

Bureaucratic reform analytical framework that used in this study referred to Cepiku \& Mititelu (2010), where the NWS analytic framework was summarized into five principles, they were: (1) bureaucracy external orientation to the fulfillment of citizens' needs; (2) the strategic role of professional managers in the implementation of policies; (3) collaboration of public and private sector; (4) representative democracy which is supported by public consultation and public participation; (5) the separation of politicsadministration with an emphasis on administration professionalization.

\section{Research Methods}

Qualitative approach in this study is intended to investigate the changes of bureaucracy on health sector in local government based on the Neo-Weberian State (NWS) perspective. The author was conducted an investigation on the real-world setting, conducted in-depth investigation on natural context, to get an understanding of bureaucrats views and what the cutting-edge contextual conditions which is different from the previous period. Real-world setting was the context referred to bureaucrats working at health area.

Setting of this study was the health area. Two bureaucrats in the health area were selected purposively as key informants, while four other informants from the relevant stakeholders. The main data of this study was obtained from interviews with informants, and added to another data from a variety of conventional and online sources. Data Analysis of this study was conducted by using a deductive approach, which has used the NWS framework to analyze the interviews transcripts and document data. The validity of this study was pursued by triangulation, member-checks, multiply description and explanation.
The design of this research was a case study. Along with the selection of the cases mentioned above, the setting of this study was the Department of Health and the General Hospital of Abunawas as the regional health at Kendari. Department of Health is implementing the element of regional autonomy that has the task of carrying out the affairs of local government on health sector based on the principle of autonomy and duty of assistance. General Hospital of Abunawas is a local government technical institute in charge of providing health services.

\section{Results and Discussion}

\section{The Bureaucracy External Orientation to the Fulfillment of Citizens' Needs}

A shift towards external orientation to the fulfillment of citizens' needs on health sector only include outdoor display, ceremonial, and get lost in a direction inconsistent. There were replacement programs because of the absence of budget; the results of survey in citizen satisfaction and public complaints were not followed; minimum service standards were more internal oriented on bureaucratic interests; the budget for the benefit of bureaucrats and institutions were extremely larger than the budget for the priority needs of the entire community.

The expected conditions are bureaucratic services focused on citizens' expectations, perceptions and priorities for improvement (Canadian Centre for Management Development, 1999). Government activities are demanddriven, to serve the greatest of people interests (Buchanan, 1977). Bureaucracy has conducted introspection through the citizens' views, then using it as a feedback to improve the effectiveness of administration (OECD, 1996). The government has always tried to minimize the anxiety and discomfort when citizens are dealing with the government (Hoogwout, 2005). Local government budgets must reflect the needs of the whole community, prioritizing to health and nutrition, education, water and sanitation (UNDESA and UNDP, 2000).

These conditions should become a trajectory of bureaucrats in health area. However, the chosen route was not a trajectory but just the zig-zag way. The bureaucratic reform process in a zig-zag way was not reflecting an approximate performance of their functions and the state objectives achievement through administration thinking method as confirmed by Tikson (2011). Furthermore, facts about bureaucratic reform on health sector was not provide a meaningful empirical support toward external orientation to the fulfillment citizens' needs, as assumed in the NWS model (Pollitt \& Bouckaert, 2004, 2011).

Bureaucracy still has internal-oriented to bureaucrats and institutions' interests. Thus, it strengthens the theoretical assumptions of state-over-citizen which stated that the activity of government would better serve its own interests rather than most people interests (Buchanan, 1977). There has been no previous empirical study on bureaucratic reforms results seen from the changes of orientation toward citizens' interests. This study that the authors have conducted might be considered as a pioneer in that direction. 


\section{International Journal of Science and Research (IJSR) \\ ISSN (Online): 2319-7064 \\ Index Copernicus Value (2013): 6.14 | Impact Factor (2014): 5.611}

\section{The Strategic Role of Professional Managers in the Implementation of Policies}

The findings of this study showed that the implementation strategy of health policies by bureaucrats in the health regions have not yet combine regulations and action speed as well. The implementation of document arranging and planning procedure is referred to the regulations that only in physical format, while other things substantially ignore the rules. Majority of the strategic policies implementation has been adopted the rapidity principle of action but others were still waiting and did not show the initiative to take a different road while doing repairs of the rules.

The expected conditions are fulfillment a structural position with an open-system; consider the seniority and qualifications, but more emphasis on the track record of achieving results and responsiveness (Pollitt \& Bouckaert, 2004, 2011). Managerial strategies in the implementation of public policies need to rely on a mix of legislation, initiatives, actions quickly, and integrity (Ayande, Sabourin \& Sefa, 2012). Modern public managers need to be oriented to "what do I need to do differently"(Christensen \& Laegreid, 2008).

These conditions should be chosen route (trajectory) by the bureaucrats in the health area. However, the route chosen still deviate from the trajectory itself. A fact about bureaucratic reform on health sector does not provide a meaningful empirical support to the strategic role of professional managers in implementation of policies as assumed in the NWS model by Pollitt \& Bouckaert (2004, 2011).

The bureaucracy has not concentrated on the role of a professional implementer. It's involved in politics, placement of structural officials were still resembling a black-box, and the objective requirements of the officials placement was replaced by subjective relations. Track record was not an important part on the selection process of bureaucratic officials. There were not the delegation of financial authority, adequate staffing and management based on written rules to officials at the lower hierarchy. Official actions were sluggish and there was no initiative to revise the regulation.

Bureaucrats that were in health area in implementing the policies was not consistently used the measure of adherence to standards that have been set at the top level as assumed in the Weberian model. Past studies by Cepiku \& Mititelu (2010) has shown that successful reform is based on legal framework. The rationalization of regulatory and compliance enforcement must be came before reform. The legal framework must be put firstly before tackling the administrative order; orientation of the civil service was a precondition for the public governance structure which is more distributed. Bureaucratic reform was still based on a legal framework that was not strong and stable, as indicated by the conflict among the rules of personnel at the central level.

Bureaucrats' compliance was still less oriented to the rules content but personally oriented to give the orders. Compliance model in Weberian bureaucracy was impersonal; bureaucrats only complied with the legal law content, not on private officials who gave the order (Weber, 1947). A past study of Priyantha (2007) has shown that the bureaucracy reform has been successful and productive in NPM perspective that required officers' compliance and legal law framework that is flexible and protective. These supporting conditions have not been created in the health area.

Bureaucrats in local health area also did not apply action speed measurements, as assumed in the NPM and NPG model. Instead, bureaucrats in the health area of Kendari were co-opted in the sala model as described by Riggs (Riggs, 1964). Relationships that existed on sala had jumbled official obligation and personal, political and administrative. Administration of sala models was characterized by the coexistence of universal norms and respect for tradition, which is reflected from the influence of family and community in decision-making positions, such as nepotism and favoritism, and the inscriptive criteria as well as achievements in public positions (Riggs, 1964).

\section{Collaboration of Public and Private Sector}

The findings of this study showed that collaboration between public and private sector in health policies area has not been built properly. Joint planning was by local governments and the private sector that only do in the new field of sanitation while planning in other fields health services were not yet. Elaboration of the role and shared responsibility has not been done. The role of the private sector is limited to provider of fund. The co-monitoring of planning implementation has not worked. Budget sharing scheme among both sectors only existed in sanitation program, while the other 19 types were not supported.

The expected conditions are the Stakeholders whom collaborate to make a decision together, to develop a joint planning, to outline the roles and responsibilities for each one, and finally to develop a monitoring plan (in Binagwa Gray, 2005). Stakeholders whom collaborate were also to maintain adequate funds together (Long \& Arnold, 1995).

In Reality, it was found that the local governments and the private sector were make decisions together in sanitation program, but has not yet developed a joint planning, outlining roles and responsibilities for each other, and develop a monitoring plan together. The budgeting commitments began to be built and the implementation form remains to be seen. Thus, the authority to make decisions was existed in the hands of local governments based on the entire process. Local governments were defining the role of the private sector. Collaborations like this based on typology of Pisano and Verganti (2008) were the kind of openhierarchical. In this type, anyone can offer her/ his ideas, but local governments define the problem and chose a solution.

The findings of this study was in accordance with previous studies of Khan et al, (2012) which showed that regional governments currently is more participatory than ever before, but for public participation, directly or indirectly, is still limited. Collaboration between regional and private government were already formed, but scope of activities were still very limited. It is not a good condition for 


\section{International Journal of Science and Research (IJSR) \\ ISSN (Online): 2319-7064 \\ Index Copernicus Value (2013): 6.14 | Impact Factor (2014): 5.611}

efficiency and responsiveness as the main feature of a professional bureaucrat. Previous study of Brown, Jr. (2008) has shown that multi-organizational structure is more efficient than the public sector itself.

These findings proved that the collaboration between local government and private sector have already established but still limited in scope. Collaboration is still need to be built and developed on a large number of urgent health care fields. Collaboration is also still to be developed towards the closed-flat type where the governments sector participants and the private sector to share their information and intellectual and make critical decisions together. It is important to encourage a sense of shared responsibility in long term.

Bureaucrats in health area in general have not consistently chosen the trajectory. Although they have entered the realm of collaboration with the private sector, but the local government is still restricting the role of private sector only in funding program. Facts about bureaucratic reform in health sector was less provide empirical support to the collaboration of public and private sector in policies implementation, as assumed in the NWS model by Pollitt \& Bouckaert (2004, 2011).

\section{Representative Democracy which is Supported by Public Consultation and Public Participation}

Bureaucratic reform in health area has not chosen a mix trajectory between a representative democracy with public consultation and public participation as mentioned. The bureaucrats were still taking a fragmented and zig-zag way. There was public participation but they are representative, there were effects on the public decision services but also kept each other with the material interests of participants, consultation was done only at the beginning process of drafting decisions. Therefore, Bureaucrats were also not formed a committee of public consultations in order to make it possible for passive consultation process. As a result, bureaucrats are more focused on the role of providing information (to inform) and not get feedback (to consult).

\section{Separation of Politics-administration with an} Emphasis on Administration Professionalism

Bureaucratic reform in health area took various routes in terms of the application in separation principle of politicsadministration with an emphasis on administration professionalism. There was a training but did not have a training criteria that applied in officials placement; top level officials are acquired income from various official sources but honorary staff's salaries were far below the minimum wage; there was employee performance appraisal and assessment organization, but the results are not used as an instrument of public management; while the autonomy and discretion are not given to bureaucrats.

Talked about autonomy and discretion, there was a tendency that the central government being an obstacle to the implementation of reform program in local government. It has been described by the enactment of legislation on civil state employees. These findings reinforce the assertion of Prasojo (2012) which states that the success of reforms in the regional level constantly prevented or inhibited by law and legislation at the national level. In this regard, Prasojo
(2012) argues that bureaucratic reform in Indonesia will be better if it implemented in top-down, from the central government to local governments.

There were not creation of political-administration separation with an emphasis on professionalism of administration at Kendari area, according to author's assumption, was closely related to the strong orientation in material interests of bureaucrats and their political superiors. It is tangible of money and occupation continuity. Bureaucrats and political superiors were equally protecting the application of patrimonial and spoil principles strongly as it eases to fulfill the material interests.

The findings of this study compared with the results of previous studies by Hadna (2007) stated that the district head has a very dominant role in determining the success of reform. It was happened that the district head has protected the principles of patrimonial and spoil. The result is politics and administrations were still blend, and bureaucrats were more focus on the politicization of administrative positions rather than professionalism. Politicization of these positions was disclosed in the earlier studies of Thoha (2010) whom stated that the personnel management after the reform issues colored of native son, collusion and nepotism. The district head and bureaucrats were alike oriented to material interests. Like a tit for tat, both stakeholders more maintain the patrimonial order and spoil because of it facilitates the fulfillment of material interests.

\section{Conclusion}

Bureaucratic reform on health sector in general did not follow the trajectory of reform that was suggested by NWS models in the fifth principles. Bureaucratic reform in the context of taking partial elements of Weberian and new elements of NPM, applied it less consistently, incorporated the objectives and means of action patrimonial, and changed policies and programs based on politics demands. Context and bureaucratic reform process on health sector was still difficult expected to be able to produce significant changes in order to create a professional employees.

Bureaucratic reform on health sector has not produced significant changes, both in the elements of Weberian and new elements of NWS model, because the influence of organization cultural factors. Organization cultural of local authorities was still characterized by the features of traditional-patrimonial culture, still lacks the features of bureaucratic/managerialism, especially post-bureaucratic/ multiculturalism that was considered to be more consistent with the values and professionalism ethics and also good public administration. The dominance of traditional patrimonial organizational culture caused bureaucratic reform process on health sector was running less followed both Weberian trajectory and NWS model in local government.

\section{References}

[1] Abramson, M., Breul, J. and Kamensky, J. 2007. "Six Trends Transforming Government: The Public 


\section{International Journal of Science and Research (IJSR) \\ ISSN (Online): 2319-7064}

Index Copernicus Value (2013): 6.14 | Impact Factor (2014): 5.611

Manager." The Quarterly for Practitioners, Spring 2007, Volume 36, Number 1.

[2] Albrow, M. 2005. Birokrasi. Yogyakarta: Tiara Wacana.

[3] Altintas, H. and Marin, M.C. 2004. Design and Timing in Bureaucratic Reform in Presidential vs Parliamentary System: A Theoretical Approach. I.Ü. Siyasal Bilgiler Fakültesi Dergisi, No. 30.

[4] Andrews, M., 2013. Explaining Positive Deviance in Public Sector Reforms in Development. Working Paper No. 267. Center for International Development (CID) at Harvard University.

[5] Andrews, M., and Shah, A. 2005. Assessing Local Government Performance in Developing Countries, in Public Services Delivery, Anwar Shah (editor). Washington D.C.: The World Bank. Pp. 17-40.

[6] Andrews, M., and Shah, A. 2003. Citizen-Centered Governance: A New Approach To Public Sector Reform, in Bringing Civility in Governance, Anwar Shah (editor). Washington D.C.: The World Bank. Pp. 153-216.

[7] APCoP-MfDR (The Asia-Pacific Community of Practice on Managing for Development Results), 2011. Framework for Results-Based Public Sector Management and Country Cases. Prepared by consultants in close cooperation with partner countries supported by the technical assistance project RETA 7744, September. (Online at http://cop-mfdr.adb.org)

[8] Arnstein, S. R. 1969. Eight Rungs on the Ladder of Citizen Participation, Journal of the American Institute of Planners, 35, 4: 216-224.

[9] Ayande, A., Sabourin, V., and Sefa, E. 2012. Managerial Execution in Public Administration: Practices of Managers When Implementing Strategic Objectives, International Journal of Business and Management; Vol. 7, No. 19: 55-75.

[10] Bernauer, T., and Koubi, V. 2006. States as Providers of Public Goods: How Does Government Size Afect Environmental Quality? Working Paper No. 14. Center for Comparative and International Studies.

[11] Binagwa, F.A. 2005. Partnership Between the Local Government Authorities (Public) and Non Governmental Organizations (private) in Tanzania Mainland. A Dissertation, St. Clements University, (online at fulgence_binagwa@yahoo.co.uk).

[12] Brown, Jr., A.H. 2008. Public Management Reform In Developing Countries: An Empirical Investigation of Operational and Financial Efficiency of Private Versus Public Airports in Latin America and The Caribbean. A Dissertation. The University of Texas at Arlington.

[13] Buchanan, James M., 1977. "Why Does Government Grow", in Thomas Borcherding (ed.), Budgets and Bureaucrats: The Sources of Government Growth. Durham: Duke University Press.

[14] Canadian Centre for Management Development, 1999. Citizen-Centered Service: Responding to the Needs of Canadian. For The Citizen-Centred Service Network. Canada: The Learning Centre, Canadian Centre for Management Development.

[15]Cepiku, D., and Mititelu, C. 2010. Public Administration Reforms in Transition Countries: Albania and Romania Between The Weberian Model and The New Public Management. Transylvanian
Review of Administrative Sciences, No. 30E/2010, pp. 55-78.

[16] Christensen, T., and Lægreid, P. 2008. Transcending New Public Management: The Transformation of Public Sector Reforms. Hampshire England : Ashgate Publishing Limited

[17]Farazmand, A. (Editor), 2007. Bureaucracy and Administration. New York: CRC Press.

[18] Hadna, A.H. 2007. Local Public Administration Reform: An Empirical Study of Local Government Reform in Indonesia during the Local Autonomy Implementation (1999-2004). A Dissertation, Universität Duisburg-Essen.

[19]Heywood, P., and Choi, Y., 2010. Health System Performance at the District Level in Indonesia After Decentralization. BioMed Central (BMC) Internatinal Health Human Right, Vol. 10 (3).

[20]Hintea, C.E. 2011. Reform and Management in Romania. Strategy and Structural Change. Revista de Cercetare Interventie Sociala, Vol. 34, pp. 177-196.

[21] Hoogwout, M. 2005. Towards a General Theory on Customer Oriented Government . Discussion paper to be presented on the NOB conference 11-11-2005, in Nijmegen, Tilburg Institute on Law, Technology and Society (online at m.hoogwout@uvt.nl).

[22] Hughes, O.E. 2003. Public Management and Administration: An Introduction. New York: Palgrave Macmillan.

[23] Khan, N., Kundi, G. M., Shah, B., Khan, A., and Kamal, S. 2012. The Prospects of New Local Government System: An Empirical Study of the Local Government in District Dera Ismail Khan (DIK)." Journal of Public Administration and Policy Research, Vol. 4(2): 42-49.

[24]Long, F. J., and Arnold, M.B. 1999. The Power of Environmental Partnerships. Fort Worth, TX: Dryden Press.

[25] Lynn Jr., L.E. 2006. Public Management: Old and New. New York: Routledge.

[26] OECD (Organisation For Economic Co-Operation And Development), 1996. Putting Citizens First: Portuguese Experience In Public Management Reform. Public Management Occasional Papers No. 13. Paris: OECD.

[27] Pisano, Gary P., and Verganti, R., 2008. Which Kind of Collaboration Is Right for You? Harvard Business Review. December. Reprint R0812F.

[28] Pollitt, C. and Bouckaert, G. 2011. Public Management Reform: A Comparative Analysis - New Public Management, Governance, and the Neo-Weberian State. Oxford: Oxford University Press.

[29] Pollitt, C. and Bouckaert G. 2004. Public Management Reform: A Comparative Analysis. Oxford: Oxford University Press.

[30] Prasojo, E., 2012. Indonesian Bureaucratic Reform in the Making. The Jakarta Post, Thu, March 08, 2012.

[31] Priyantha, I. R. 2007. New Public Personnel Management Reforms at Work in Sri Lanka: A Waddling Effort of Transforming Civil Service? Paper presented at NFU Conference on "Making Institutions Work for the Poor" Chr. Michelsen Institute, Bergen, Norway, 5-7 November. (Online at http://ssrn.com/abstract=1094309) 
[32]Riggs, F.W. 1964. Administration in Developing Countries: The Theory of Prismatic Society. Boston: Houghton Mifflin.

[33] Thoha, M. 2010. Manajemen Pegawai Negeri Sipil di Indonesia. Jakarta: Kencana Prenada Mulia.

[34] Tikson, Deddy T., 2011. "Tantangan Administrasi Negara Menghadapi Ketimpangan Global". Pidato penerimaan jabatan Guru Besar dalam bidang Ilmu Administrasi Pembangunan pada Program Studi Ilmu Administrasi Negara, Fakultas Ilmu Sosial dan Ilmu Politik Universitas Hasanuddin, Makassar, 12 Juli 2011.

[35] UNDESA (The United Nations, Department for Economic and Social Affairs) and UNDP (the United Nations Development Programme), 2000. Responding to Citizens' Needs: Local Governance and Social Services for All. Report of the United Nations Global Forum on Local Governance and Social Services for All, Stockholm, Sweden, 2-5 May 2000.

[36] Weber, M. 1947. From Max Weber: Essays in Sociology. Edited by H.H. Gerth and C. Wright Mills. New York: Oxford University Press.

[37] Weber, M. 1946. Max Weber: The Theory of Social and Economic Organization. Edited by A.M. Henderson and Talcott Parsons. New York: The Free Press.

[38] Wescott, Clay G., 2008. "World Bank Support for Public Financial Management: Conceptual Roots and Evidence of Impact". Background Paper to Public Sector Reform: What Works and Why? An IEG Evaluation of World Bank Support. IEG Working Paper 2008. Washington, D.C.: The World Bank.

[39] Williamson, Oliver E., 1995. Chester Barnard and the Incipient Science of Organization. In Organization Theory: From Chester Barnard to the Present and Beyond. Edited by Oliver E. Williamson. New York, Oxford: Oxford University Press, p. 172-206.

[40] Wilson, J. Q., 1989. Bureaucracy. What Government Agencies Do and Why They Do It. New York: Basic Books.

[41]Wilson, W., 1887. The Study of Administration. Political Science Quarterly, June II (2), 197-222.

[42] Yin, R.K., 2011. Qualitative Research: From Start to Finish. New York: The Guilford Press.

[43] Zammuto, R.F. and Krakower, J.Y., 1991. Quantitative and Qualitative Studies of Organisational Culture. Research in Organisational Change and Development, Vol. 5, pp. 83-114. 